Escritura y Pensamiento 20-24(40-48), 2021, 463-464

\title{
Nakasone, Danie1. Reír hacia atrás. Lima: Pakarina Ediciones, 2021, 64pp.
}

Apenas tenemos en nuestras manos el poemario de Daniel Nakasone, nos invita a pensar en su particular titulo, pues nos lleva a la reflexión aun sin haber abierto el libro. Y es que la expresión "Reír hacia atrás" conlleva aparentemente dos significados: el primero es la risa desatada, la que conduce hacia un éxtasis de gozo; y la otra, más profunda, donde la melancolía despierta el recuerdo de una aparente dicha ya abandonada. El autor escoge lo segundo. En los versos no hallamos jolgorio sino introspección. Reír hacia atrás fractura la corporeidad de nuestros sentidos para explorarnos intimamente. De esta forma comienza con un pertinente y sorprendente epílogo que dice lo siguiente: "En una casa semivacía existieron por un corto periodo dos ánimas, una que sabía que estaba muerta y la otra que no. El ánima que no sabe que ha muerto, ¿convencerá a su par de que ambas se hallan con vida?" Marcando el derrotero con el que debemos abordar sus textos.

Los poemas situados en flash back, son agrupados en secciones numeradas de manera descendente que nos conducen a una sensación de encierro que anhelan liberación, aunque para nuestra desazón, el remolino de emociones nos aloja aún más en la melancolía de la quietud. Los poemas van desde lo descriptivo y lo reflexivo hasta la oscuridad de las palabras.

$\mathrm{Y}$ es por eso que el primer poema llamado Dador de Ruido, nos introduce a la incertidumbre por no comprender lo observa- 
ble para finalmente contemplar pasivamente la realidad a través de la lejanía de una ventana.

Reir hacia atrás es un libro sobre la búsqueda. Es el retornar hacia el origen poético de las palabras y definir el equilibro entre la ensoñación y lo humano, porque se sabe, como decía Alain Bosquet, "Al fondo de cada palabra / asisto a mi nacimiento". En cada poema las imágenes no solo crean, también definen y luchan por significar. Desde lo más orgánico y tangible hasta la impulsividad de lo imaginario. Así nos dice: "Ansío el tren la línea engranaje lejano/ Yo busco en esta mano arroyo el devenir/ Anodino/ leucocito/ demonificado / Bramido de avispas mortecinas/ Toda anestesia se inyecta para crear un nuevo alarido". El poeta intenta cruzar el umbral donde el recuerdo y la invención se pierden. Reconstruye con ensoñación la realidad que se le escapa. “¡Hemos sido dotados de extrema fuerza / Solo para emplearla en una empresa volátil! / Lo cual quiere decir que hay habitaciones / Que no han sido construidas para nosotros. / Lo cual quiere decir que nunca pudimos salir / O bien que jamás podremos entrar". Las imágenes estallan con las palabras para luego contemplar el desvanecimiento de la luminosidad en la tranquilidad de su conclusión. Este poemario está construido con ladrillos transparentes donde se nos revelará sus formas y matices si estamos dispuestos a regresar al principio de su arquitectura. (Carlos Eduardo Luján Andrade) 
donde se explica la composición estructural de cada texto para encontrar semejanzas como el tono oral, el suspenso narrativo, los biografemas o los personajes conceptuales que para Morales Mena consiguen darle consistencia a la escritura ensayística del autor de Conversación en La Catedral.

Al terminar la lectura del libro de Javier Morales Mena reconocemos que esta investigación ha empezado a cubrir un vacío en el corpus crítico sobre los ensayos literarios de Vargas Llosa; además, este está escrito con una rigurosidad hermenéutica donde rebate posturas consagradas y abre derroteros de lectura; y, por ello, nos permite generar nuevas preguntas sobre la vigencia de la escritura reflexiva del Nobel peruano. (Agustín Prado Alvarado) 